\title{
PELABELAN ANTIAJAIB JARAK PADA BEBERAPA KELAS GRAF TERKAIT GRAF HELM
}

\author{
SULISTYO DWI SANCOKO ${ }^{1 *}$ \\ ${ }^{1}$ Program Studi Informatika FTIE Universitas Teknologi Yogyakarta \\ *sulistyods91@gmail.com
}

\begin{abstract}
ABSTRAK
Diberikan graf sederhana dan tidak berarah $G=(V(G), E(G))$ dengan order $n$ dan fungsi bijektif $f$ yang membawa setiap anggota $V(G)$ ke himpunan $\{1,2, \cdots, n\}$. Bobot titik $v \in V(G)$ didefinisikan sebagai $w_{f}(v)=\sum_{x \in N(v)} f(x)$. Fungsi $f$ disebut pelabelan antiajaib jarak jika bobot setiap titik di $G$. Graf yang dapat dilabeli dengan pelabelan antiajaib jarak disebut graf antiajaib jarak. Pada tulisan ini dibuktikan bahwa graf helm $H_{n}$, graf bunga $F_{n}$, graf bunga tertutup $C F_{n}$, dan graf serupa bunga $l F_{n}$ merupakan graf antiajaib jarak untuk $n \geq 3$.
\end{abstract}

Kata Kunci: Pelabelan antiajaib jarak, graf, helm, bunga, bunga tertutup, serupa bunga

\begin{abstract}
Given a simple and undirected graph $G=(V(G), E(G))$ with order $n$ and a bijective function $f$ which map every element of $V(G)$ to a set $\{1,2, \cdots, n\}$. The point weight $v \in V(G)$ is defined as $w_{f}(v)=$ $\sum_{x \in N(v)} f(x)$. The function $f$ is called a distance anti-magic labeling if the weight of each point on $G$. A graph that can be labeled with distance anti-magic labeling is called a distance anti-magic graph. In this paper, it is proven that helmet graph $H_{n}$, flower graph $F_{n}$, closed flower graph $C F_{n}$, and flower $l F_{n}$ are distance anti-magic graph for $n \geq 3$.
\end{abstract}

Keywords: Anti-magic distance labeling, graphs, helmets, flowers, closed flowers, like flowers

\section{Pendahuluan}

Teori graf pertama kali lahir pada tahun 1736 yang diperkenalkan oleh Euler setelah muncul masalah jembatan Konigsberg di Prusia yaitu mengenai kemungkinan seseorang dapat melewati setiap jembatan yang ada tepat satu kali dan kembali ke tempat semula [1]. Dalam teori graf, jembatan tersebut dipandang sebagai sisi yang menghubungkan dua kota, yang selanjutnya kota-kota tersebut dipandang sebagai titik. Graf didefinisikan sebagai himpunan pasangan berurutan $G=(V(G), E(G))$ dengan $V(G)$ dan $E(G)$ berturut-turut menyatakan himpunan semua titik dan himpunan semua sisi di $G$ [2]. Graf mempunyai banyak jenis diantaranya graf regular, graf lengkap, graf path, graf bintang, dan sebagainya. Dalam kaitannya dengan pembentukan kelas graf baru dapat dilakukan dengan mengoperasikan dua graf atau bisa juga dengan menambah atau mengurangkan beberapa komponen yang ada pada graf yang sudah ada. Dengan adanya kelas graf baru tersebut mengakibatkan banyak penelitian yang dapat dilakukan terhadap graf - graf tersebut. 
Penelitian teori graf berkembang dengan sangat pesat baik dalam segi teori maupun dari segi penerapannya untuk berbagai bidang. Salah satu penelitian yang berkembang adalah mengenai pelabelan graf. Pelabelan graf adalah suatu pemetaan yang membawa elemen-elemen graf $G$ ke suatu bilangan bulat positif atau tak negatif. Dalam hal ini, yang dimaksud dengan elemen-elemen graf adalah semua titik di $G$ atau semua sisi di $G$ [3]. Lebih lanjut, bilanganbilangan bulat positif atau tak negatif yang menjadi kodomain dari pemetaan tersebut dinamakan sebagai label. Pelabelan graf dibedakan menjadi tiga berdasarkan domain yang digunakan dalam pemetaan tersebut. Apabila daerah asal dari pelabelan tersebut adalah himpunan semua titik di $G$ maka pelabelan tersebut dinamakan pelabelan titik. Sedangkan apabila daerah asal dari pelabelan tersebut adalah himpunan semua sisi di $G$ maka pelabelannya dinamakan pelabelan sisi. Lebih lanjut, apabila daerah asalnya adalah gabungan antara himpunan semua titik dan himpunan semua sisi di $G$ maka dinamakan pelabelan total. Sampai saat ini telah banyak dilakukan penelitian mengenai pelabelan graf. Pelabelan graf pun memiliki banyak jenis yang diterapkan dalam berbagai macam kelas graf [3]. Salah satu pelabelan graf yang ada adalah pelabelan graf ajaib jarak dan pelabelan graf antiajaib jarak.

Pelabelan ajaib jarak didefinisikan sebagai suatu pemetaan bijektif $f: V(G) \rightarrow$ $\{1,2, \ldots, n\}$ sedemikian sehingga bobot setiap titik $v \in V(G)$ bernilai sama. Dalam hal bobot titik $v \in V(G)$ tersebut semuanya mempunyai nilai yang berbeda maka pelabelan tersebut dinamakan pelabelan jarak antiajaib [4]. Selanjutnya, telah dilakukan penelitian dan diperoleh hasil bahwa graf sun $S_{n}$, graf roda $W_{n}$ dengan $n>5$, graf fan $F_{n}$ dengan $n>4$ dan graf friendship $f_{n}$ berturut-turut merupakan graf antiajaib jarak. [4] Selanjutnya dari penelitian lain juga diperoleh hasil bahwa graf Harary $H_{4, n}$, graf Petersen yang diperumum $P(n, k)$ dan hasil operasi join dari keduanya berturut-turut merupakan graf antiajaib jarak[5].

Tulisan ini merupakan hasil penelitian terhadap graf helm dengan memberikan pelabelan terhadap semua titiknya sehingga diperoleh label titik yang semuanya berbeda dan selanjutnya diperoleh bobot setiap titiknya juga berbeda. Pengembangan dari graf helm tersebut dilakukan dengan menambahkan beberapa sisi yang menghubungkan beberapa titik pada graf helm tersebut sedemikian sehingga diperoleh graf baru yang selanjutnya dinamakan sebagai graf bunga dan graf bunga tertutup. Selanjutnya, dari graf bunga dilakukan pengurangan beberapa sisinya sehingga diperoleh suatu graf baru yang dinamakan sebagai graf serupa bunga. Lebih lanjut, pada graf bunga, graf bunga tertutup dan graf serupa bunga tersebut juga dilakukan pelabelan antiajaib jarak pada setiap titiknya.

\section{Tinjauan Pustaka}

Pada pelabelan graf diketahui bahwa kodomain dari fungsi pelabelan tersebut merupakan bilangan bulat positif atau tak negatif, dengan demikian operasi penjumlahan dapat dilakukan pada label-label yang berhubungan dengan elemen-elemen dalam graf tersebut.

Definisi 2.1. Diberikan graf $G=(V(G), E(G))$ dengan order $n$ dan fungsi bijektiff : $V(G) \rightarrow$ $\{1,2, \ldots, n\}$. Bobot titik $v \in V(G)$ dituliskan $w_{f}(v)$ didefinisikan sebagai

$$
w_{f}(v)=\sum_{x \in N(v)} f(x)
$$

dengan $N(v)=\{u \in V(G) \mid u v \in E(G)\}$ 
Definisi 2.2. Diberikan graf $G=(V(G), E(G))$ dengan order $n$ dan fungsi bijektif $f: V(G) \rightarrow$ $\{1,2, \ldots, n\}$. Fungsi $f$ disebut pelabelan antiajaib jarak jika $w_{f}(u) \neq w_{f}(v)$, untuk setiap $u, v \in V(G)$ dengan $u \neq v$.

Lebih lanjut, suatu graf yang dilengkapi dengan pelabelan antiajaib jarak disebut sebagai graf antiajaib jarak. Selanjutnya, pada [6] telah ditunjukkan bahwa graf lintasan $\boldsymbol{P}_{\boldsymbol{n}}$ untuk $\boldsymbol{n} \neq$ $\mathbf{3}$ dan graf sikel (cycle) $\boldsymbol{C}_{\boldsymbol{n}}$ dengan $\boldsymbol{n} \neq \mathbf{4}$ merupakan graf antiajaib jarak.

\section{Pelabelan Antiajaib Jarak Pada Graf Helm}

Pada bagian ini, dijelaskan bahwa graf helm $H_{n}$ merupakan graf antiajaib jarak. Sebelumnya akan dikenalkan graf roda dan graf helm sebagai berikut.

Definisi 3.1. Graf roda $W_{n}$ adalah graf yang diperoleh dari graf sikel $C_{n}$ dengan menambahkan satu titik yang dihubungkan dengan semua titik pada graf sikel tersebut. [7]

Definisi 3.2. Graf helm $H_{n}$ adalah graf yang diperoleh dari sebuah graf roda $W_{n}$ dengan menambahkan daun (titik berderajat 1) pada setiap titik pada cycle dari graf roda tersebut.[3]

Pada graf helm $H_{n}$, indeks $n$ menyatakan banyaknya titik pada graf cycle yang ada pada graf helm $H_{n}$ tersebut. Lebih lanjut, karena $n$ adalah order graf cycle pada graf helm $H_{n}$ haruslah $n \geq 3$. Sebuah graf helm $H_{n}$ disajikan pada Gambar 1 .

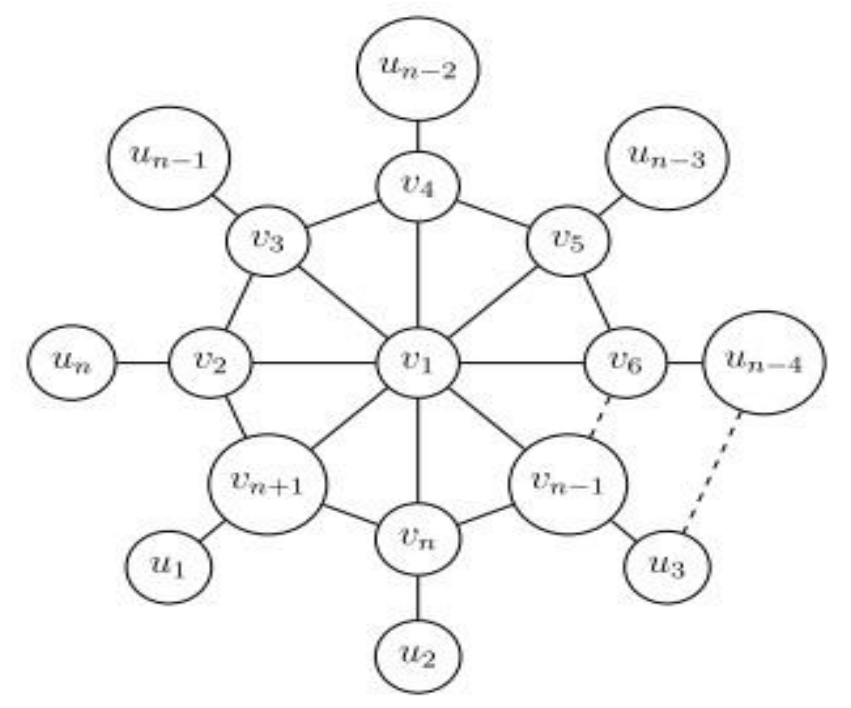

Gambar 1. Graf helm $H_{n}$ dilengkapi dengan label titik

Dari Gambar 1., diperoleh himpunan semua titik dan himpunan semua sisi pada graf helm $H_{n}$ berturut-turut dinyatakan dengan $V\left(H_{n}\right)=\left\{v_{1}, v_{2}, \cdots, v_{n}, v_{n+1}, u_{1}, u_{2}, \cdots, u_{n}\right\}$ dan $E\left(H_{n}\right)=\left\{v_{1} u_{i} \mid 2 \leq i \leq n+1\right\} \cup\left\{v_{i} v_{i+1} \mid 2 \leq i \leq n\right\} \cup\left\{v_{n+1} v_{2}\right\} \cup\left\{v_{i} u_{j} \mid 2 \leq i \leq n+\right.$ $1, j=n-i+2\}$. Dengan demikian, graf helm $H_{n}$ mempunyai $2 n+1$ titik dan $3 n$ sisi. Selanjutnya, graf helm $H_{n}$ merupakan graf antiajaib jarak sebagaimana dibuktikan pada Teorema 3.2.

Teorema 3.2. Graf helm $H_{n}$ merupakan graf antiajaib jarak, untuk $n \geq 3$.

Bukti. Dimisalkan bahwa $V\left(H_{n}\right)=\left\{v_{1}, v_{2}, \ldots, v_{n}, v_{n+1}, u_{1}, u_{2}, \ldots, u_{n}\right\}$. Dibentuk fungsi $f$ : $V\left(H_{n}\right) \rightarrow\{1,2,3, \ldots, n, n+1, \ldots, 2 n+1\}$ dengan 


$$
\begin{aligned}
& f\left(v_{i}\right)=i \quad, 1 \leq i \leq n+1, \\
& f\left(u_{j}\right)=n+1+j, 1 \leq j \leq n .
\end{aligned}
$$

Jelaslah bahwa untuk setiap $u_{i}, v_{j} \in V\left(H_{n}\right)$ berbeda diperoleh nilai $f\left(v_{i}\right)$ dan $f\left(u_{j}\right)$ juga berbeda sehingga $f$ merupakan fungsi bijektif. Selanjutnya, diperoleh bobot setiap titik di graf helm $H_{n}$ sebagai berikut

$$
\begin{array}{cc}
w_{f}\left(v_{i}\right)=\left\{\begin{array}{lc}
\frac{n(n+3)}{2} & , i=1 \\
3 n+6 & , i=2 \\
2 n+i+4 & , 3 \leq i \leq n \\
2 n+5 & , i=n+1
\end{array}\right. \\
w_{f}\left(u_{j}\right)=n-j+2 & , 1 \leq j \leq n .
\end{array}
$$

Karena diperoleh bobot setiap titik graf helm $H_{n}$ nilainya berbeda satu sama lain, terbukti bahwa graf helm $H_{n}$, dengan $n \geq 3$, adalah graf antiajaib jarak.

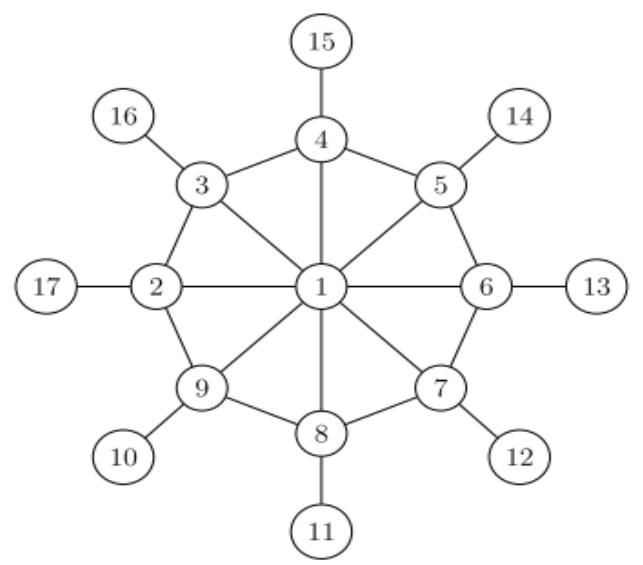

Gambar 2. Pelabelan antiajaib jarak pada graf helm $\boldsymbol{H}_{8}$

Selanjutnya, sebagai contoh pelabelan pada graf helm diberikan pada Gambar 2.

\begin{tabular}{|l|c|l|}
\hline \multicolumn{3}{|c|}{ Bobot titik pada graf helm $H_{8}$} \\
\hline$w_{f}\left(v_{1}\right)=44$ & $w_{f}\left(v_{7}\right)=27$ & $w_{f}\left(u_{4}\right)=6$ \\
$w_{f}\left(v_{2}\right)=30$ & $w_{f}\left(v_{8}\right)=28$ & $w_{f}\left(u_{5}\right)=5$ \\
$w_{f}\left(v_{3}\right)=23$ & $w_{f}\left(v_{9}\right)=21$ & $w_{f}\left(u_{6}\right)=4$ \\
$w_{f}\left(v_{4}\right)=24$ & $w_{f}\left(u_{1}\right)=9$ & $w_{f}\left(u_{7}\right)=3$ \\
$w_{f}\left(v_{5}\right)=25$ & $w_{f}\left(u_{2}\right)=8$ & $w_{f}\left(u_{8}\right)=2$ \\
$w_{f}\left(v_{6}\right)=26$ & $w_{f}\left(u_{3}\right)=7$ & \\
\hline & & \\
\hline
\end{tabular}

Tabel 1. Daftar Bobot Titik Graf Helm $\boldsymbol{H}_{n}$ 
Dari Tabel 1., terlihat bahwa label setiap titiknya berbeda dan hasil penghitungan bobot titiknya juga berbeda. Dengan demikian, graf helm $H_{8}$ merupakan graf antiajaib jarak.

Selanjutnya, dengan menghubungkan semua titik pendant atau titik berderajat satu pada graf helm $H_{n}$ ke titik pusatnya maka akan diperoleh graf bunga dan dapat ditunjukkan bahwa graf bunga juga merupakan graf antiajaib jarak seperti yang dijelaskan pada bagian 4 .

\section{Pelabelan Antiajaib Jarak Pada Graf Bunga}

Pada bagian ini, diberikan graf baru sebagai modifikasi graf helm yaitu graf bunga sebagaimana diberikan pada definisi berikut.

Definisi 4.1. Graf bunga $F_{n}$ adalah graf yang diperoleh dari graf helm $H_{n}$ dengan menghubungkan setiap titik pendant (titik berderajat 1) ke titik pusatnya..

Sebagai contoh graf bunga $F_{8}$, disajikan pada Gambar 3 berikut.

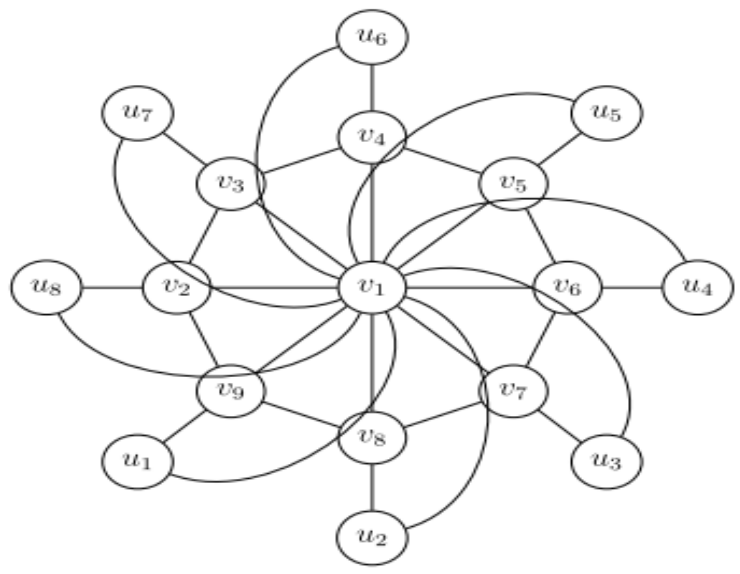

Gambar 3. Graf bunga $F_{8}$ yang dilengkapi dengan label titik.

Berdasarkan Gambar 3. diperoleh himpunan titik dan himpunan sisi graf bunga berturutturut dinyatakan dengan $V\left(F_{n}\right)=\left\{v_{1}, v_{2}, \ldots, v_{n}, v_{n+1}, u_{1}, u_{2}, \ldots, u_{n}\right\}$ dan $E\left(F_{n}\right)=$ $\left\{v_{1} v_{i} \mid 2 \leq i \leq n+1\right\} \cup\left\{v_{1} u_{j} \mid 1 \leq j \leq n\right\} \cup\left\{v_{i} v_{i+1} \mid 2 \leq i \leq n\right\} \cup\left\{v_{n+1} v_{2}\right\} \cup\left\{v_{i} u_{j} \mid 2 \leq\right.$ $i \leq n, j=n-i+2\}$. Dengan demikian, graf bunga $F_{n}$ memiliki $2 n+1$ titik dan $4 n$ sisi, dengan $n \geq 3$. Selanjutnya, graf bunga $F_{n}$ merupakan graf antiajaib jarak sebagaimana dinyatakan pada Teorema 4.2.

Teorema 4.2. Graf bunga $F_{n}$ merupakan graf antiajaib ajaib, untuk $n \geq 3$.

Bukti. Dimisalkan bahwa $V\left(F_{n}\right)=\left\{v_{1}, v_{2}, \ldots, v_{n}, v_{n+1}, u_{1}, u_{2}, \ldots, u_{n}\right\}$. Dibentuk fungsi $f$ : $V\left(F_{n}\right) \rightarrow\{1,2,3, \ldots, n, n+1, \ldots, 2 n+1\}$ dengan definisi

$$
\begin{aligned}
& f\left(v_{i}\right)=i \quad, 1 \leq i \leq n+1, \\
& f\left(u_{j}\right)=n+1+j, 1 \leq j \leq n .
\end{aligned}
$$

Karena label setiap $v_{i}, u_{j} \in V\left(F_{n}\right)$ berbeda maka $f$ merupakan fungsi bijektif. Selanjutnya, diperoleh bobot setiap titik di graf bunga $F_{n}$ sebagai berikut: 


$$
\begin{aligned}
& w_{f}\left(v_{i}\right)=\left\{\begin{array}{lr}
n(2 n+3) & , i=1 \\
3 n+6 & , i=2 \\
2 n+i+4 & , 3 \leq i \leq n \\
2 n+5 & , i=n+1
\end{array}\right. \\
& w_{f}\left(u_{j}\right)=n-j+3 \quad, 1 \leq j \leq n \text {. }
\end{aligned}
$$

Mudah diperiksa bahwa bobot titik-titik dari graf bunga $F_{n}$ semuanya berbeda. Dengan demikian, terbukti bahwa graf bunga $F_{n}$ adalah graf antiajaib jarak.

Selanjutnya, sebagai contoh diberikan graf bunga $F_{8}$ yang dilengkapi dengan label titik seperti pada Gambar 4. yang selanjutnya dapat ditentukan bobot setiap titik pada graf bunga $F_{8}$ seperti pada Tabel 2.

\begin{tabular}{|l|l|l|}
\hline \multicolumn{3}{|c|}{ Bobot titik pada graf bunga $\boldsymbol{F}_{\mathbf{8}}$} \\
\hline$w_{f}\left(v_{1}\right)=152$ & $w_{f}\left(v_{7}\right)=27$ & $w_{f}\left(u_{4}\right)=7$ \\
$w_{f}\left(v_{2}\right)=30$ & $w_{f}\left(v_{8}\right)=28$ & $w_{f}\left(u_{5}\right)=6$ \\
$w_{f}\left(v_{3}\right)=23$ & $w_{f}\left(v_{9}\right)=21$ & $w_{f}\left(u_{6}\right)=5$ \\
$w_{f}\left(v_{4}\right)=24$ & $w_{f}\left(u_{1}\right)=10$ & $w_{f}\left(u_{7}\right)=4$ \\
$w_{f}\left(v_{5}\right)=25$ & $w_{f}\left(u_{2}\right)=9$ & $w_{f}\left(u_{8}\right)=3$ \\
$w_{f}\left(v_{6}\right)=26$ & $w_{f}\left(u_{3}\right)=8$ & \\
\hline
\end{tabular}

Tabel 2. Daftar Bobot Setiap Titik Graf Bunga $F_{8}$

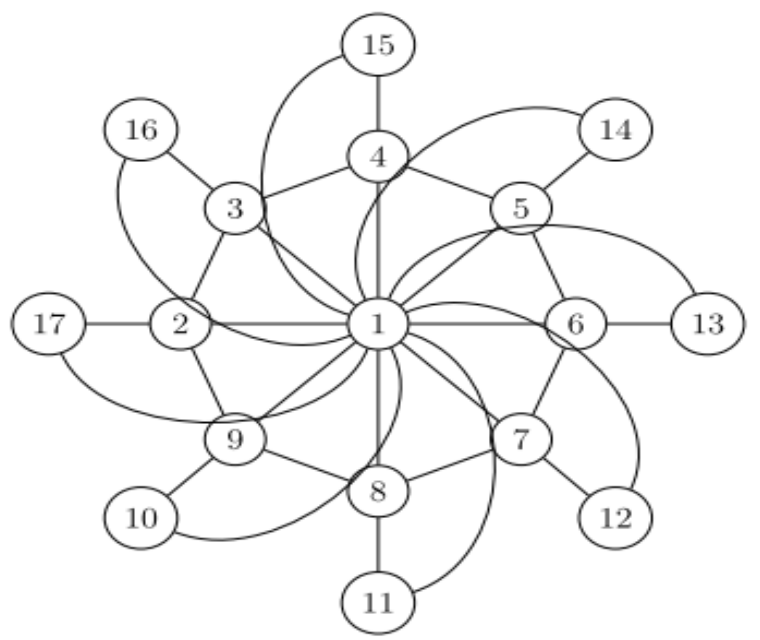

Gambar 4. Pelabelan antiajaib jarak pada graf bunga $F_{8}$

Dari Tabel 2., terlihat bahwa label setiap titik di $F_{8}$ berbeda dan hasil penghitungan bobot titiknya juga berbeda. Dengan demikian, graf bunga $F_{8}$ merupakan graf antiajaib jarak.

\section{$5 \quad$ Pelabelan Antiajaib Jarak Pada Graf Bunga Tertutup}

Pada bagian ini, diberikan kelas graf baru yang diperoleh dari modifikasi graf bunga $F_{n}$.

Definisi 5.1. Graf bunga tertutup $C F_{n}$ didefinisikan sebagai graf yang diperoleh dari graf bunga $F_{n}$ dengan menambahkan sisi yang menghubungkan setiap dua titik berderajat 2 pada graf bunga tersebut. 
Pada graf bunga tertutup $C F_{n}$, indeks $n$ menyatakan banyaknya titik pada graf cycle yang menjadi badan dari graf bunga tertutup $C F_{n}$ tersebut. Lebih lanjut, karena $n$ adalah order dari graf cycle pada graf bunga tertutup $C F_{n}$ maka haruslah $n \geq 3$. Sebagai gambaran dari graf bunga tertutup $C F_{n}$ disajikan pada Gambar 5 berikut.

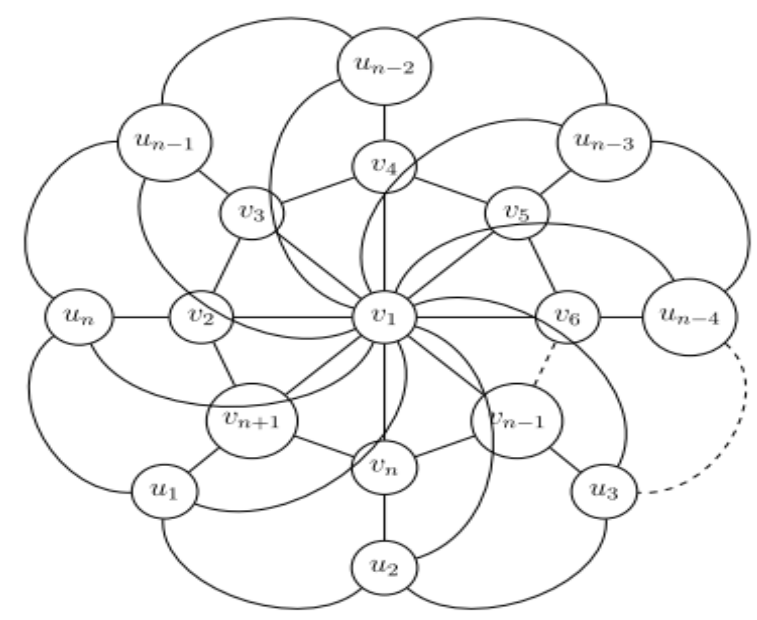

GAMBAR 5. Graf bunga tertutup $C F_{n}$ dilengkapi dengan pelabelan titik

Graf bunga tertutup mempunyai himpunan titik dan himpunan sisi berturut-turut dituliskan dengan $V\left(C F_{n}\right)=\left\{v_{1}, v_{2}, \ldots, v_{n}, v_{n+1}, u_{1}, u_{2}, \ldots, u_{n}\right\}$ dan $E\left(C F_{n}\right)=\left\{v_{1} v_{i} \mid 2 \leq\right.$ $i \leq n+1\} \cup\left\{v_{1} u_{j} \mid 1 \leq j \leq n\right\} \cup\left\{v_{i} v_{i+1} \mid 2 \leq i \leq n\right\} \cup\left\{v_{n+1} v_{2}\right\} \cup\left\{v_{i} u_{j} \mid 2 \leq i \leq n, j=\right.$ $n-i+2\} \cup\left\{u_{j} u_{j+1} \mid 1 \leq j \leq n-1\right\} \cup\left\{u_{n} u_{1}\right\}$ Selanjutnya, graf bunga tertutup $C F_{n}$ merupakan graf antiajaib jarak sebagaimana dibuktikan pada Teorema 5.2.

Teorema 5.2. Graf bunga tertutup $C F_{n}$ merupakan graf antiajaib jarak, untuk $n \geq 3$.

Bukti. Dimisalkan bahwa $V\left(C F_{n}\right)=\left\{v_{1}, v_{2}, \ldots, v_{n}, v_{n+1}, u_{1}, u_{2}, \ldots, u_{n}\right\}$. Dibentuk fungsi $f$ : $V\left(C F_{n}\right) \rightarrow\{1,2,3, \ldots, n, n+1, \ldots, 2 n+1\}$ dengan definisi

$$
\begin{aligned}
& f\left(v_{i}\right)=i \quad, 1 \leq i \leq n+1 \\
& f\left(u_{j}\right)=n+1+j, 1 \leq j \leq n
\end{aligned}
$$

Mudah diperiksa bahwa label titik-titik graf bunga tertutup $C F_{n}$ semuanya berbeda sehingga $f$ merupakan fungsi bijektif. Selanjutnya, diperoleh bobot dari setiap titik di graf bunga tertutup $C F_{n}$ sebagai berikut:

$$
\begin{gathered}
w_{f}\left(v_{i}\right)=\left\{\begin{array}{lr}
n(2 n+3) & , i=1 \\
3 n+6 & , i=2 \\
2 n+i+4 & , 3 \leq i \leq n \\
2 n+5 & , i=n+1
\end{array}\right. \\
w_{f}\left(u_{j}\right)=\left\{\begin{array}{lr}
4 n+6 & , j=1 \\
3 n+j+5 & , j \leq n-1 \\
3 n+5 & , j=n
\end{array}\right.
\end{gathered}
$$


Mudah dilihat bahwa bobot titik-titik graf bunga tertutup $C F_{n}$ semuanya berbeda. Dengan demikian, terbukti bahwa graf bunga tertutup $C F_{n}$ adalah graf antiajaib jarak.

Selanjutnya, sebagai contoh diberikan graf bunga tertutup $C F_{8}$ yang dilengkapi dengan label titik seperti pada Gambar 6. Dari gambar tersebut dapat ditentukan bobot setiap titik pada graf bunga tertutup $C F_{8}$ sebagai berikut.

\begin{tabular}{|l|l|l|}
\hline \multicolumn{3}{|c|}{ Bobot Titik Dari Graf Bunga Tertutup $\boldsymbol{C F}_{\boldsymbol{n}}$} \\
\hline$w_{f}\left(v_{1}\right)=152$ & $w_{f}\left(v_{7}\right)=27$ & $w_{f}\left(u_{4}\right)=33$ \\
$w_{f}\left(v_{2}\right)=30$ & $w_{f}\left(v_{8}\right)=28$ & $w_{f}\left(u_{5}\right)=34$ \\
$w_{f}\left(v_{3}\right)=23$ & $w_{f}\left(v_{9}\right)=21$ & $w_{f}\left(u_{6}\right)=35$ \\
$w_{f}\left(v_{4}\right)=24$ & $w_{f}\left(u_{1}\right)=38$ & $w_{f}\left(u_{7}\right)=36$ \\
$w_{f}\left(v_{5}\right)=25$ & $w_{f}\left(u_{2}\right)=31$ & $w_{f}\left(u_{8}\right)=29$ \\
$w_{f}\left(v_{6}\right)=26$ & $w_{f}\left(u_{3}\right)=32$ & \\
\hline
\end{tabular}

Tabel 3. Daftar Bobot Titik Pada Graf Bunga Tertutup $\mathrm{CF}_{8}$

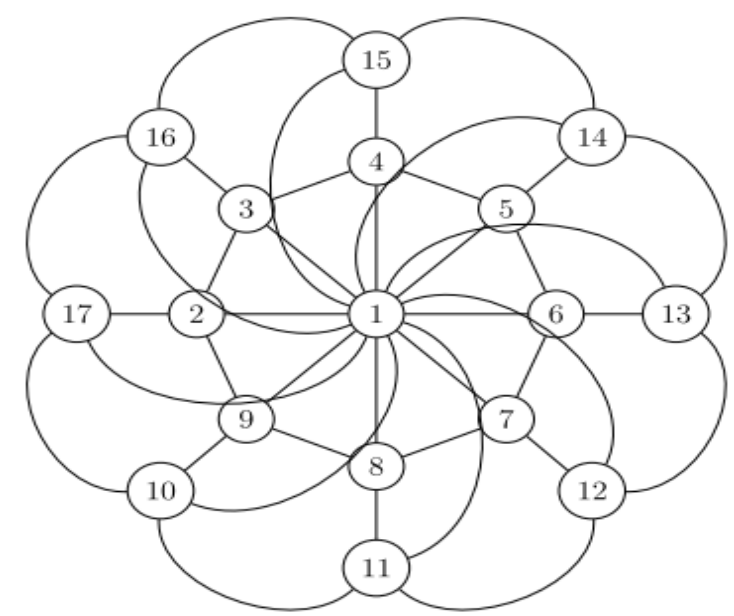

Gambar 6. Pelabelan antiajaib jarak pada graf bunga tertutup $C F_{8}$

Dari Tabel 3., terlihat bahwa label setiap titiknya berbeda dan bobot titik-titiknya juga semuanya berbeda. Dengan demikian, graf bunga tertutup $\boldsymbol{C F}_{\mathbf{8}}$ merupakan graf antiajaib jarak.

\section{Pelabelan Antiajaib Jarak Pada Graf Serupa Bunga}

Definisi 6.1. Graf serupa bunga $l F_{n}$ adalah graf yang diperoleh dari graf bunga $F_{n}$ dengan menghilangkan semua sisi yang menghubungkan setiap titik di cycle dari graf bunga dengan titik pusat pada graf bunga tersebut.

Pada graf serupa bunga $l F_{n}$, indeks $n$ menyatakan banyaknya titik pada graf cycle yang menjadi badan dari graf serupa bunga $l F_{n}$ tersebut. Lebih lanjut, karena $n$ adalah order dari graf cycle pada graf serupa bunga $l F_{n}$ maka $n \geq 3$. Graf serupa bunga $l F_{n}$ mempunyai $2 n+1$ titik dan $3 n$ sisi. Sebagai gambaran dari graf serupa bunga $l F_{n}$ disajikan pada Gambar 7 . 


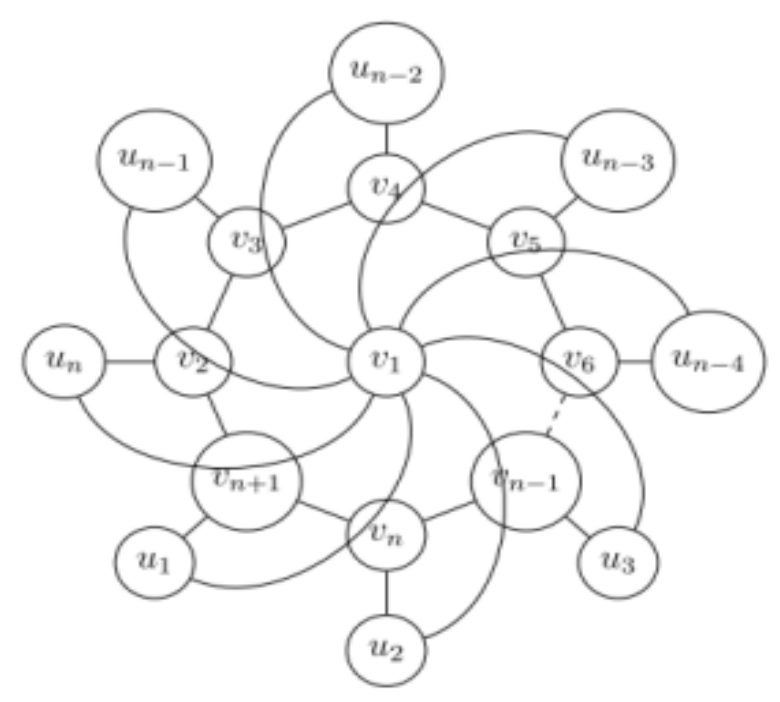

Gambar 7. Graf serupa bunga $l F_{n}$ dilengkapi dengan label titik

Selanjutnya, graf serupa bunga $l F_{n}$ merupakan graf antiajaib jarak sebagaimana dinyatakan pada Teorema 4.

Teorema 4. Graf serupa bunga tertutup $l F_{n}$ merupakan graf antiajaib jarak, untuk $n \geq 3$.

Bukti. Dimisalkan bahwa $V\left(l F_{n}\right)=\left\{v_{1}, v_{2}, \ldots, v_{n}, v_{n+1}, u_{1}, u_{2}, \ldots, u_{n}\right\}$. Dibentuk fungsi $f$ : $V\left(l F_{n}\right) \rightarrow\{1,2,3, \ldots, n, n+1, \ldots, 2 n+1\}$ dengan definisi

$$
\begin{aligned}
& f\left(v_{i}\right)=i \quad, 1 \leq i \leq n+1 \\
& f\left(u_{j}\right)=n+1+j, 1 \leq j \leq n
\end{aligned}
$$

Mudah diperiksa bahwa label titik-titik graf serupa bunga $l F_{n}$ semuanya berbeda sehingga $f$ merupakan fungsi bijektif. Selanjutnya, diperoleh bobot dari setiap titik di graf serupa bunga $l F_{n}$ sebagai berikut

$$
\begin{aligned}
& w_{f}\left(v_{i}\right)=\left\{\begin{array}{lr}
\frac{3 n(n+1)}{2} & , i=1 \\
3 n+5 & , i=2 \\
2 n+i+3 & , 3 \leq i \leq n \\
2 n+4 & , i=n+1
\end{array}\right. \\
& w_{f}\left(u_{j}\right)=n-j+3, \quad 1 \leq j \leq n .
\end{aligned}
$$

Selanjutnya, dengan mudah diketahui bahwa bobot titik-titik graf serupa bunga $l F_{n}$ semuanya berbeda. Dengan demikian, terbukti bahwa graf serupa bunga $l F_{n}$ adalah graf antiajaib jarak.

\section{Kesimpulan}

Dalam artikel ini telah dibuktikan bahwa untuk $n \geq 3$, graf helm $H_{n}$, graf bunga $F_{n}$, graf bunga tertutup $C F_{n}$ dan graf serupa bunga $l F_{n}$ merupakan graf antiajaib jarak. 


\section{Daftar Pustaka}

[1] F. Harary, Graph theory. 2018.

[2] J. A. Bondy and U. S. R. Murty, Graph Theory with Applications. 1976.

[3] J. A. Gallian, “A dynamic survey of graph labeling," Electron. J. Comb., 2018.

[4] R. Simanjuntak and K. Wijaya, "On Distance Antimagic Graphs," 2013, [Online]. Available: https://www.academia.edu/18847673/On_Distance_Antimagic_Graphs.

[5] A. K. Handa, A. Godinho, and T. Singh, "Some distance antimagic labeled graphs," 2016, doi: 10.1007/978-3-319-29221-2_16.

[6] A. K. Handa, A. Godinho, T. Singh, and S. Arumugam, "Distance antimagic labeling of join and corona of two graphs," AKCE Int. J. Graphs Comb., 2017, doi: 10.1016/j.akcej.2017.04.003.

[7] K. H. Rosen, Discrete Mathematics and Its Applications, Sixth. New York: McGraw.Hill International Edition, 2007. 